\title{
THE MANAGEMENT OF CASUALTIES FROM THE BALLYKINLER BOMB EXPLOSION
}

\author{
COLONEL R. G. ROBINSON, M.B., M.F.C.M., Late R.A.M.C. \\ Military Wing, Musgrave Park Hospital
}

SUMMARY: The management of a group of patients with bomb injuries, admitted to the Military Wing of the Musgrave Park Hospital, is examined, and their handling by the limited number of staff is discussed. Clinical details of the casualties and their treatment are to be reviewed separately, outline details only being given here.

\section{Introduction}

On the morning of 28 October 1974, Musgrave Park Military Wing had 65 occupied beds against its authorized establishment of. 66 . At 1015 hours a bomb exploded without warning in a vehicle parked outside the Sandes Home near Abercorn Barracks, Ballykinler, County Down.

News of the bombing and that the first casualties were on their way by air, was received at the Military Wing just before 1130 hours. All departments were informed and :

a. The Operating Theatre was opened. b. Both surgical teams were called to readiness. c. The helicopter landing zone was manned. d. All patients fit to leave hospital were discharged. e. Off-duty staff were called in.

The first lift of six casualties arrived by helicopter at 1145 hours, and the second of eight less seriously injured patients at 1205 -hours. Later in the day five patients were transferred in from the Downpatrick Hospital, and a further five next morning. The admissions are listed in Table I.

\section{Management}

After initial triage by the senior surgeon and the resuscitation of the first lift of casualties, one surgical team began operating in the Military Wing Theatre and, some 30 minutes later, the second team in the Nuffield Theatre of the civilian hospital. One was reinforced by the casualty officer, and the other by a medical officer from 45 Commando Royal Marines who had arrived that morning on a short attachment to the Military Wing.

Outside the theatre, the physician monitored the condition of the patients awaiting operation, assisted by two nursing officers. He also overlooked the Intensive Care Unit. Meanwhile the Regimental Medical Officer of 3rd Royal Green Jackets, who had heard about the incident on the radio and came to help, took on the duties of casualty officer. He dealt with the second lift of casualties.

The Regimental Medical Officer of 1st Duke of Edinburgh's Royal Regiment, the resident doctor at Ballykinler, acted as liaison officer at the site of the incident, and subsequently with the Downpatrick Hospital to which a number of injured had been evacuated by road (Table II). He also dealt personally with those patients needing only first aid. 
Table I

Patients admitted to Military Wing Musgrave Park

\begin{tabular}{|c|c|c|c|}
\hline Lift & Patient & Diagnosis & Disposal \\
\hline 1st & $\mathrm{L} / \mathrm{Cpl} \mathrm{AC}$ & Extensive blast injuries & Died 28 Ootober \\
\hline 1st & Pte TLGM & $\begin{array}{l}\text { Lacerations back and neck. Burns } \\
\text { hands }\end{array}$ & Tidworth 4 November \\
\hline 1 st & Cpl DJP & Compound fracture forearm & Woolwich 4 November \\
\hline 1st & Pte GRQ & Multiple blast injuries & Aldershot 21 November \\
\hline 1 st & Pte RWR & Multiple lacerations & Woolwich 8 November \\
\hline 1st & Cpl RLS & Compound fracture skull & Woolwich 4 November \\
\hline 2nd & Dvr F & Laceration scalp & Suture and R.T.U. \\
\hline 2nd & Pte AJH & Multiple lacerations and burns & Unit sick bay 31 October \\
\hline 2nd & L/Cpl I & Multiple lacerations & Suture and R.T.U. \\
\hline 2nd' & Dvr J & Lacerated chest & Suture and R.T.U. \\
\hline 2nd & Pte GLM & $\begin{array}{l}\text { Burns hands and neck. Lacerated } \\
\text { chest }\end{array}$ & Aldershot 4 November \\
\hline 2nd & Dvr RGM & Lacerations head and back & Tidworth 8 November \\
\hline 2nd & Pte $\mathrm{O}$ & $\begin{array}{l}\text { Lacerations head and back. FB } \\
\text { back }\end{array}$ & Tidworth 7 November \\
\hline 2nd & Pte BMS & $\begin{array}{l}\text { Burns head and neck. Blast in- } \\
\text { juries }\end{array}$ & R.T.U. 31 October \\
\hline $3 \mathrm{rd}$ & L/Cpl DGA & $\begin{array}{l}\text { Lacerations head and nose. Burns } \\
\text { hands }\end{array}$ & Unit sick bay 31 October \\
\hline 3rd & Cpl JC & $\begin{array}{l}\text { Blast injury and multiple lacera- } \\
\text { tions }\end{array}$ & R.T.U. 5 November \\
\hline $3 r d$ & Pte TK & $\begin{array}{l}\text { Blast damage lungs. Lacerations. } \\
\text { Burns hands and neck }\end{array}$ & Millbank 4 November \\
\hline $3 \mathrm{rd}$ & Pte JEP & $\begin{array}{l}\text { Burns face and hands. Lacerated } \\
\text { feet }\end{array}$ & Aldershot 4 November \\
\hline 3 rd & L/Cpl SSL & $\begin{array}{l}\text { Lacerations face and shoulders. } \\
\text { Burns hands }\end{array}$ & Unit sick bay 31 October \\
\hline 4th & Dvr EJA & Laceration buttocks & Mı!lbank 8 November \\
\hline 4th & L/Cpl JM & Lacerations legs and scalp & Woolwich 4 November \\
\hline 4th & Dvr RM & Laceration left calf & Aldershot 4 November \\
\hline 4th & Pte MS & Lacerations hands scalp and ear & Woolwich 31 October \\
\hline 4th & L/Cpl SSC & $\begin{array}{l}\text { Head wound involving VII nerve } \\
\text { and middle ear }\end{array}$ & Millbank 4 November \\
\hline
\end{tabular}

Later in the day arrangements were made with the Royal Air Force to put on an emergency aeromedical evacuation flight next morning. This counteracted the overloading of the wards and gained space to be able to accept further transfers in from Downpatrick Hospital. Next morning Tuesday 29 October 1974 the initial bedstate was 71 . 
Table II

Patients at Downpatrick Hospital

\begin{tabular}{|l|l|}
\hline \multicolumn{1}{|c|}{ Number } & \multicolumn{1}{|c}{ Disposal } \\
\hline Five & Returned to Unit (R.T.U.) 28 October \\
\hline One & Transferred to Neurosurgical Unit, Royal Victoria Hospital 28 October \\
\hline Five & Transferred to Military Wing Musgrave Park 28 October \\
\hline Five & Transferred to Military Wing Musgrave Park 29 October \\
\hline
\end{tabular}

Subsequently nine patients were evacuated by air to England, and five patients were transferred in from the Downpatrick Hospital. The Delayed Primary Sutures (D.P.S.) following the initial debridements were performed on Friday 1 November, Saturday 2 and Monday 4 November. The first of the patients from the incident to be evacuated to Military Hospitals in England left by air on Monday 4 November, and the last on 29 November.

\section{Examination of procedures}

\section{Warning of the incident}

Warning was received in the Military Wing by telephone. The message contained accurate information concerning the first lift. Action was taken as described above, and the wing administrative officer obtained accurate information of the second lift from the scene of the incident.

The essential information required is:

a. How many casualties are there. b. How bad are they. c. When will they get here. d. Where are they coming from.

To reduce the possibility of misleading messages being taken, suitably printed message boards are held beside the telephone and radio in reception, and when each unit arrives in the Province, the Regimental Aid Post staff is briefed on this drill.

\section{Nursing support}

Nursing support for the reception of the casualties was organised by the Deputy Matron, in the absence of the Matron. She arranged for:

a. Recall of off-duty ward staff. b. Ward sisters to identify and discharge patients nominated as being fit for discharge that day. c. Resuscitation department to be reinforced by extra experienced nursing staff. d. Wards to be rearranged with empty beds near the principal nursing-station.

\section{The reception and movement of casualties}

The reception and movement of casualties fell into three phases (see Table I and Figure 1).

Phase I. Six seriously ill patients who were seen by a surgeon on arrival at reception, and taken straight to the resuscitation room which is adjacent to the 


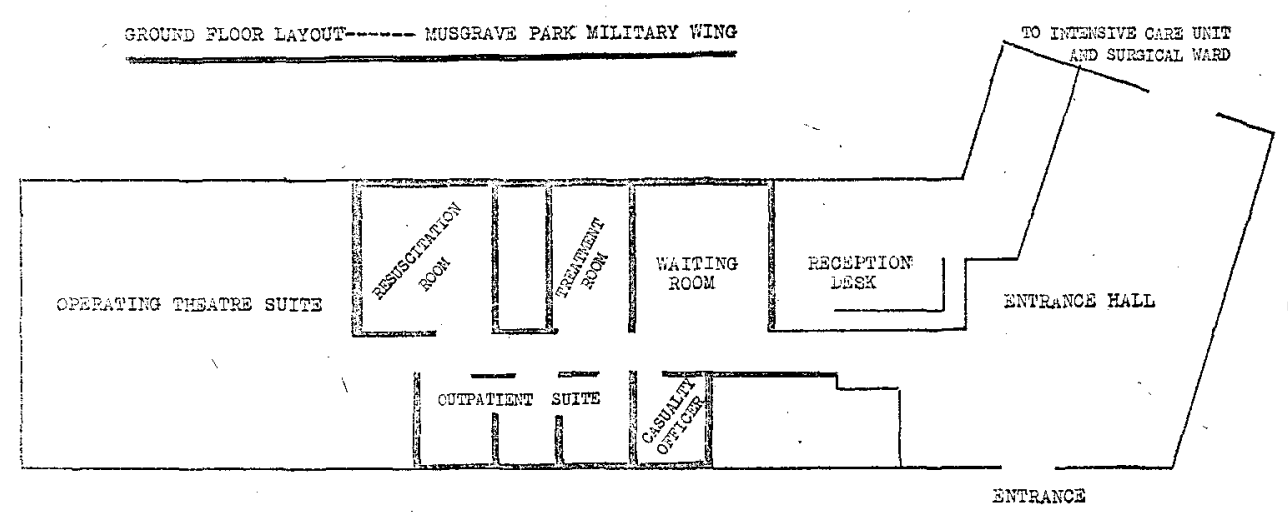

Fig. 1.

operating theatre. Those for whom there was no room went to the outpatients rooms opposite.

Phase II. Eight less seriously ill sitting cases who were taken straight into the outpatients waiting room, and from there brought forward either to the casualty officer's consulting room, or to the treatment room.

Phase III. Two lifts of each of five patients transferred in from the Downpatrick Hospital.

Movement of patients was at first hampered by there being only two stretcher trolleys and four adjustable theatre trolleys available. Later twelve adjustable theatre trolleys were borrowed from the civilian hospital which meant that stretchers no longer had to be left on the floor, and manpower no longer wasted on stretcher bearing.

\section{The intensive care unit}

The unit received three patients during this incident; however the limited number of nursing staff at the Military Wing meant that there were not enough nurses to man the department for long, and reinforcements had to be sought from other Military Hospitals. Thanks are due to the Military Hospitals in England which provided the reinforcements, and to the men themselves for their splendid work on this and other occasions.

\section{Discussion}

The Military Wing Musgrave Park Hospital is a small but busy hospital which provides cover for members of the Armed Forces in Northern Ireland, and emergency cover for those within reach by ambulance or helicopter.

The experience built up there during the emergency, the well planned and well equipped Casualty Department; and some timely outside assistance, enabled the small staff, and the limited capacity of 66 authorized beds, to accept 19 patients on the first day, and 5 patients on the next day.

A careful study of what took place was made to ensure that all the lessons there to be learnt were noted. This report is based on that study. Certain lessons were particularly well illustrated. 


\section{The liaison officer}

The liaison officer at the scene of the incident provided timely and accurate information for the hospital. He also sorted the casualties so that the more seriously injured were in the first lift.

\section{The triage}

The triage of the casualties on arrival was done by the senior surgeon who was able to make a logical plan for the management of the patients taking into account information received from the scene of the incident.

\section{Normal drills}

Normal drills were followed and accommodation used for its normal purpose, thus enabling everybody to work as efficiently as possible.

Utilisation of beds was effectively raised by:

a. Crisis expansion beds being pre-positioned. b, Discharge of those patients whose condition allowed. c. Transfer to low dependancy beds of suitable patients. d. Aeromedical evacuation of patients to England to make room for further transfers in.

\section{The constraint}

The constraint imposed by the politico-military situation which demanded beds to be available at all times to cope with a possible subsequent incident.

\section{Trolleys}

Trolleys were in short supply. Experience over the past few years has led some Belfast hospitals to replace examination couches by 'theatre type' trolleys. In addition to having the necessary break to enable them to be used for examination, they should ideally also be able to go into the head down position, and have facility for $\mathrm{X}$-rays to be taken without moving the patient.

\section{R.A.M.C. PRIZES}

\section{Course Prizes}

137 Postgraduate Medical Officers Course 138 Postgraduate Medical Officers Course Sidney Herbert-Captain (Miss) J. E. K. Sidney Herbert-Captain J. G. MaloneDorman Lee

\section{Annual Prizes}

Montefiore-Captain P. M. de Glanville De Chaumont-Captain M. D. Murton

Parkes-Captain J. G. Malone-Lee Dorman

Ranald Martin-Captain (Miss) J. E. K. and Captain K. W. Truter
Tulloch Memorial-_Captain J. W. Lowe

J. R. Rees-Captain P. M. de Glanville

Marshall Webb-Captain (Miss) J. E. K.

Dorman 